\title{
The role of social innovation in criminal justice reform and the risk posed by proposed reforms in England and Wales
}

Total word count 9800 including Abstract and Bibliography

\section{Abstract}

The UK government has called for a rehabilitation revolution in England and Wales and put its faith in market testing. It hopes this will lead to greater innovation, resulting in reductions in re-offending while also driving down costs. However, many of the most innovative developments in criminal justice over recent decades have come through social innovation. Examples include restorative justice and justice reinvestment. In this article we argue that while social innovation will respond to some extent to conventional economic policy levers such as market testing, de-regulation and the intelligent use of public sector purchasing power it is not simply an extension of the neo-liberal model into the social realm. Social innovation, based on solidarity and reciprocity, is an alternative to the logic of the neo-liberal paradigm. In policy terms, the promotion of social innovation will need to take account of the interplay between government policy, social and cultural norms and individual and social capacity. Current proposals for reforming the criminal justice system may not leave sufficient scope to develop the conditions for effective social innovation. 


\section{Keywords}

Social innovation, social impact market, criminal justice policy, market-testing

\section{Introduction}

Rates of re-offending for offenders under the jurisdiction of the Criminal Justice System in England and Wales are relatively high. According to recent figures from the Ministry of Justice (2013a) around 550,000 adult offenders were cautioned, convicted or released from custody in $2010 / 11$. Of these around 140,000 were reconvicted within a year: a proven re-offending rate of 25.4 percent. For some groups of offenders the rate is higher. The proven re-offending rate for those released from custody was 47.2 percent, for drug-misusing offenders it was 57.6 percent and for offenders serving a prison sentence of less than 12 months it was 57.8 percent (Ministry of Justice, 2013a).

The government's preferred strategy for reducing re-offending while also reducing costs is a combination of market testing, commissioning strategies that focus on outcomes and a diversification of the supplier base. The intention is thus to create a 'revolution' in how offenders are managed as enshrined in the current government's 
Coalition Agreement:

“We will introduce a 'rehabilitation revolution' that will pay independent providers to reduce reoffending, paid for by the savings this new approach will generate within the criminal justice system." (HM Government, 2010: 23)

This approach, elaborated in Ministry of Justice (2010), is consistent with a wider public service reform agenda. The Open Public Services White Paper sets out the principle of 'open public services':

"In the services amenable to commissioning, the principles of open public services will switch the default from one where the state provides the service itself to one where the state commissions the service from a range of diverse providers." (HM Government, 2011: 29)

Advantages of a purchaser/provider split are cited as encouraging new, innovative providers, allowing payment by results and/or incentives for supporting particular social groups and enabling the disaggregation of services into specialist functions (HM Government, 2011). Proponents of market testing, particularly where Payment by Results is part of the equation argue that 'freeing' up providers to deliver services in different ways will encourage greater innovation. XXXXXXX suggest that this broad approach seems to be a rejection of the prevailing 'New Public Management' approach 
which has dominated the public sector (6 and Peck, 2004) and, increasingly, the voluntary sector services over recent years.

Latterly the government appears to have adopted a more ideologically driven approach. For probation services the approach, set out in two recent policy papers on Transforming Rehabilitation (Ministry of Justice, 2013b and 2013c) is for the majority of community-based offender services (community sentences and licenses) to be subject to competition with providers drawn from the private and voluntary sectors. Probation Trusts will be abolished. In the resulting national competition for 21 geographical 'bundles' of resettlement services existing probation services will be allowed to join the competition by setting up new independent entities (such as employee-led mutuals). Work with high-risk offenders, assessments and court reports will be undertaken by a new national probation service. The Ministry of Justice stated that, driving down costs for rehabilitation services would allow such services to be extended to resettlement of short-term prisoners. 
Extending provision to prisoners serving sentences of less than 12 months will require a substantial new investment ${ }^{1}$. This will need to be achieved in the context of reducing budgets. Mills et al. (2010) note that following the 2010 spending review the Ministry of Justice will have to make overall resource savings of 23 percent in real terms by 2014-15. This is a huge challenge. The government recognises this. In its most recent consultation the Ministry of Justice said:

\begin{abstract}
"Given the challenging financial context, we will need to increase efficiency and drive down costs to enable us to extend provision to those released from shortterm sentences. We therefore intend to begin a process of competition to open up the market and bring in a more diverse mix of providers, delivering increased innovation and improved value for money. (emphasis added) (Ministry of Justice, 2013b: 5)."
\end{abstract}

This raises several important questions. First, what scale of savings can efficiencies deliver, without compromising the quality of services, in the context of a system where

\footnotetext{
${ }^{1}$ The previous Labour administration came close to extending provision to this group ('Custody Plus') but although legislation was passed to allow this (The Criminal Justice Act 2003) provision was never implemented (Justice Committee, 2008) because of the cost implications.
} 
substantial sums have already been taken out of the system? Looking at efficiency savings across the public sector HM Treasury (2009: 7) concluded that: “. . . the public sector should be able to achieve a reduction in annual back office costs of around 20 to 25 percent by the end of the next three years." However, the new probation contracts will be let at a point at which many of these back office savings should already have been realised. For instance, one of the Treasury's examples in their 2009 report was HM Prison Service implementing a shared services centre that delivers finance, procurement and HR functions for 128 prisons and was expected to deliver savings of around a third in relevant back office functions. However, even if this was not the case and 20 to 25 percent savings in back office costs could still be made this would not deliver overall criminal justice savings of 23 percent and, additional savings on top of that to pay for the new service delivered to prisoners serving less than 12 months. This is because back office costs will only make up a relatively small proportion of overall costs. Some commentators argue that 'contracting out' probation services has the potential to delivery dramatic savings. Chambers (2013) for example notes that the only core element of probation work that has ever been put out to competition, Community Payback in London, is now being provided at around 60 percent of the previous costs demonstrating "the scale of savings in the $£ 1$ billion offender community services budget that are possible through private sector financial 
management and disciplines" (Chambers, 2013: 6). However, this analysis is

premature. SERCO only took over the contract in October 2012 and these are

projected savings not actual ones. But, even if we accept Chamber's argument it is clear that to achieve greater savings real innovation that can deliver 'game changing' solutions will be needed. Serco's delivery model for Community Payback involves a blend of new management systems and new partnerships between private, public and not-for-profit organisations (Hornby, 2013).

The second question that is then raised is, under what circumstances has innovation been delivered in the criminal justice system previously? It is our contention that many of the potentially 'game changing' reforms in criminal justice have been, in one way or another 'social innovations'. As we discuss in more detail below one example of social innovation in the criminal justice sector that is also widely cited in the social innovation literature is Restorative Justice (for example Mulgan et al., 2007). Another example is Justice Reinvestment in the US.

In the remainder of this article we discuss the concept of social innovation, look in more detail at social innovation in the criminal justice system, examine the literature on social innovation to better understand some of the levers and facilitators of social innovation and finish by asking what the prospects for social innovation in the criminal 
justice system are in light of the proposed reforms.

\section{What is social innovation?}

The concept of social innovation has become popular among academics and policy makers alike in recent years (see for instance Mulgan, 2006; Pol and Ville, 2009;

Howaldt and Schwarz, 2010, Franz et al., 2012; Moulaert et al., 2013; OECD, 2011;

European Commission, 2010). That societies are innovative is not a novel idea: classical sociologists rightly pointed out that societies are sets of dynamic interactions between individuals and institutions. What is new today is the attempt to instrumentalise social relationships to formulate and implement strategies that tackle societal problems or as Franz et al. (2012) put it, it is the intention to use social practices which distinguishes social innovation from mere social change. Similar Howaldt and Schwarz (2010) for whom the new or innovative in social innovation unfolds on the level of social practice as an intentional reconfiguration of existing social practices.

There is mounting awareness that economic growth is not the only answer to current challanges. As British Prime Minister David Cameron puts it "GDP is an incomplete way of measuring a country's progress" (David Cameron, 2010). In recent years, understanding social impact of policy and its relationship with wellbeing has become increasingly important. The government defines social impact as those: 
“impacts on society which are not traded explicitly and are essential for capturing the true costs and benefits of policies, including their effects on wellbeing. Social impacts reflect changes to attitudes, values, beliefs and behaviour, and contribute to wellbeing". (Harper and Price, 2011)

Means of measuring wellbeing and evaluating programmes and policies designed to achieve it have proliferated (see for instance Dolan et al., 2011 and Michaelson et al., 2012). Methodologies such as the Social Return on Investment analysis have sought to make clearer the link between investment in programmes and policies and social outcomes including well-being.

Social innovation is social impact driven. In broad terms, there is consensus that social innovation implies new concepts and partnerships to improve efficiency on one hand and meeting social needs on the other hand (European Commission, 2010 Moulaert et al., 2013).

For instance, social innovation has been described as 'the generation and implementation of new ideas about how people should organise interpersonal activities or social interactions to meet one or more common goals' (Mumford, 2002). Defined in this way, social innovation implies new sets of social relations to deliver products and services. These may include new partnerships across sectors (Kania and 
Kramer, 2011; Leadbeater, 2007), flattening of hierarchies, coproduction and personalisation (Leadbeater, 2004; Jacobs and Jostmeier, 2010; the term 'prosumer' gained some popularity in this context see Blättel-Mink and Hellman, 2010). In this case innovations are implemented on the level of operational practice and become instrumental to 'the way in which things are getting done'. Rather than being the primary goal of the innovation, process oriented social innovation is a means to an end.

Social innovation may also refer to new products and services that address social needs. Because social impact is its primary outcome, we call this type of innovation goal oriented social innovation. The Young Foundation for example understands social innovation as those 'new ideas that work in meeting social goals' (Young Foundation, 2007). Mulgan (2006) defines social innovation as 'innovative activities and services that are motivated by the goal of meeting a social need'. Phills et al. (2008) conceptualise social innovation in similar terms as 'a novel solution to a social problem that is more effective, efficient, sustainable or just than existing solutions and for which the value created accrues primarily to society as a whole rather than private individuals' (see also Franz et al., 2012). 
Some definitions of social innovation combine goal and process oriented innovation. Murray et. al. (2010) suggests that social innovations are those 'innovations that are social in both their means and their ends'. The European Commission in its report 'Empowering People, Driving Change Social innovation in the European Union' adopted the same definition and argues that social innovations are not only good for society but also enhance society's capacity to act (European Commission, 2010: 33, see also President Barroso's (2009) speech on 'How to boost "social innovation'). In this ideal type of social innovation the process is part of the outcome and social innovation is an end in itself.

\section{Social innovation in the criminal justice system}

At first glance the criminal justice system might not seem a promising sector for social innovation. The requirements of justice evoke concepts such as certainty, consistency and adherence to well-defined processes, not ideas that are necessarily compatible with innovation. Some of the agencies in the criminal justice system such as the judiciary with their concern for precedent and the police with their 'command and control', hierarchical structure might not be ones that readily spring to mind when we think of social innovation. Nevertheless there is a rich tradition of social innovation in the criminal justice system that embodies many key dimensions of 'social' innovations. 
Taking a long view, arguably the probation service itself has its roots in social innovation. Early work on rehabilitation in the UK is often traced back to the 1870 s and work undertaken by the Church of England Temperance Society in Southwark, London ${ }^{2}$. The Temperance Society and other voluntary organisations appointed missionaries to the London Police Courts. Offenders began to be released into the community on the understanding that they kept in touch with an appointed missionary and accepted the guidance that they were given by this missionary. The probation service was placed on a statutory basis in 1907 and the courts were able to employ 'probation officers' to fulfil this role. Between 1910 and 1930 the prison population halved and this was attributed in large part to the role of the new probation service ${ }^{3}$.

More recent examples within the criminal justice system also illustrate the key dimensions or facets of social innovation. When significant cases of the power of social innovation from across the social policy spectrum are identified an example that is frequently cited is the Restorative Justice movement (for example Mulgan et al., 2007). Social innovations often reinvent older, social patterns and practices. The idea of restorative justice is an ancient one. Braithwaite (2002) suggests that interest was

\footnotetext{
${ }^{2}$ http://probationassociation.co.uk/about-us/history-of-probation.aspx, http://www.nationalprobationservice.co.uk/page1.html

${ }^{3}$ http://probationassociation.co.uk/about-us/history-of-probation.aspx, http://www.nationalprobationservice.co.uk/page1.html
} 
rekindled in the West from the 1970 s onwards as a result of various projects including an experimental victim-offender reconciliation programme in Ontario, the New Zealand idea of family group conferences, Canadian First Nations' healing circles and various less visible African restorative justice institutions. This illustrates another common facet of social innovation: its utilisation of global links and knowledge transfer - an approach which, in the case of restorative justice made it easier to learn lessons and share ideas (Braithwaite, 2002).

Also key to social innovation are new processes that make use of social relations. Historically, there is nothing new in this. The foundations of the Criminal Justice System in England and Wales are built on the input of the citizenry and the voluntary sector. Consider for instance the central role of juries and magistrates in the court process or the origins of policing in Anglo-Saxon Britain with Parish Constables (Joyce, 2011) and the role still played in policing by voluntary Special Constables. The important role for the citizenry and community sector is captured in the modern Community Justice movement - a concept that has clear overlaps with social innovation. For example, the Community Justice concept of Clear and Karp (2000) brings together three major themes in reducing criminal behaviour: restorative justice; prevention and early intervention; and community strengthening and selfdetermination. Specific examples might include community policing (Goldstein, 1990) 
or community courts (Mair and Millings, 2011). The North Liverpool Community Justice Centre, based on a US project has a number of features redolent of social innovation including the application of a problem-solving approach to criminal cases; a sole Judge who can sit as a District Judge or a Crown Court Judge; co-location of the relevant criminal justice agencies; provision of a range of services available to the community as a whole (including advice on housing, help with drug and alcohol problems, legal and financial advice) and a Community Engagement Team that works proactively to engage with the community (Mair and Millings, 2011).

Successful social innovations do not tend to follow a linear growth trend or innovation cycle but typically go through a developmental 'arc' from idea to mass movement: "First, it is ridiculed. Second, it is violently opposed. Third, it is accepted as being selfevident." (Schopenhauer quoted in Mulgan et al., 2007). Moreover, the social innovation paradigm 'is essentially characterised by the opening of the innovation process to society. Companies, universities and research institutes, citizens and customers become relevant actors in an open, user-led innovation process' (Hochgerner et al., 2011). 
It is worth reflecting on how restorative justice has moved from the periphery of the criminal justice system in the UK to take on a much more prominent role and feature in many aspects of mainstream service provision.

As we have discussed, key to social innovation is the utlilisation of non-financial, social resources to achieve important goals. Often this implies more democratic methods of service design and delivery. Thus, Restorative Justice is a co-produced approach to delivering justice (Weaver, 2011). It brings together communities resources to work with offenders. In most models of Restorative Justice some degree of agency is conferred on the offender. It is not uncommon for social innovations to resonate both with principles of localism and personalisation. Restorative Justice tends to embody both of these principles. In this sense it has some parallels with the development of personalisation in the UK health and social care sector, another example regularly cited in the social innovation literature (Mulgan et al., 2007).

Another common dimension to many social innovations is the innovative use of new technology and social media (Goldsmith et al., 2010). The Justice Reinvestment movement, which started in the USA but is now spreading is an example of social innovation that illustrates the use of technology, in this case the rise of personal computing and Geographical Information Systems (XXX et al., 2013). These new 
technologies made 'justice mapping', one of the building blocks of Justice Reinvestment possible. The Justice Reinvestment movement started in the US at around the turn of the new millennium with analysis identifying 'million dollar blocks': certain communities where states were spending up to a million dollars per block to "cycle residents back and forth from prison each year" (Cadora, 2007: 11; Allen, 2007). Early Justice Reinvestment projects explored whether some of this million-dollars per block might be better spent on other criminal justice or, ideally, broader social justice interventions, "to invest in public safety by reallocating justice dollars to refinance education, housing, healthcare, and jobs." (ibid.). Latterly, argue XXXXXXX Justice Reinvestment has tended to shed its more radical aspirations to deliver social justice and instead focus more narrowly on system 're-engineering', in process losing perhaps the characteristics of a movement for social innovation.

A dimension common to many social innovations is innovation in financing. Currently, in the UK Social Impact Bonds are attracting much attention as an innovative financial instrument in the field of social innovation. The first Social Impact Bond was created in the criminal justice system to fund a new service at HMP Peterborough. The Ministry of Justice has signed a contract with Social Finance (2010) to attempt to reduce the reoffending of a cohort of 3,000 adult males who are discharged from HMP Peterborough having served sentences of less than 12 months in custody. Disley et al. 
(2011) report that investors have put $£ 5 \mathrm{~m}$ in social impact bonds to fund the rehabilitation work and that they could earn a return of up to $f 8 m$ from the government and the Big Lottery Fund if re-offending among three cohorts, each of a thousand offenders falls by 10 percent or if the rate of re-offending for all 3,000 offenders falls by at least 7.5 percent. The result of the commissioning process is a new scenario in which government has no direct control over the choice of service providers - this is the choice of the intermediary (Mulgan et al., 2011) and where the downside risk is transferred to the investor.

Finally, social innovations are often a response to the most pressing social needs. In the criminal justice system this could be interpreted in a number of ways. One might in terms of harm that those who re-offend cause. Returning to Restorative Justice it is interesting to note that this approach has been successfully used with high risk offenders and those with complex needs. For example, in their review, Sherman and Strang (2007) note that the most positive results in Restorative Justice have frequently come when it has been applied to work with higher risk offenders. The Circles of Support programme ${ }^{4}$ developed in Canada where a group of volunteers forms into a community around a sex offender is another example of social innovation in response

\footnotetext{
${ }^{4}$ http://www.circles-uk.org.uk/
} 
to a situation where the harm from re-offending is high. We might also consider pressing social needs in terms of the complexity of offenders' needs. In England and Wales a group with complex needs and a high risk of re-offending are those sentenced to prison terms of less than one year and it is this group that are the focus on the HMP Peterborough Social Impact Bond (see above).

\section{Social innovation as a contested concept}

The brief survey of some possible examples of social innovation in the criminal justice system also alerts us to some of the conceptual and ideological issues raised by social innovation.

Take, for instance, Social Impact Bonds. Do they represent an opportunity to engage a wide range of providers in the delivery of criminal justice and, as such a financial framework for promoting social innovation, or are they a mechanism for increasing competition and outsourcing state services to the private sector in a straightforward extension of the neo-liberal paradigm? Looking at the Peterborough initiative, our reading of Disley et al. (2011) is that the financial backers of the SIB are charities and 
trusts that pursue social ends: none are from the private sector ${ }^{5}$. The provider delivering the rehabilitation services at HMP Peterborough on behalf of Social Finance is St. Giles Trust, a not-for-profit organisation which trains ex-offenders to use their skills and first-hand experience to help others through peer-led support and claims that "Around one-third of our staff are ex-offenders who now support others" 6 . This looks like 'classic' social innovation. On the other hand, as Taylor (2013) notes, the Work Programme, where Payment by Results contracts are used on a much larger scale and are more established has not always been kind to third sector providers with many unable to manage the financial demands of $\mathrm{PbR}$ contracts. Others are ideologically opposed to PbR seeing it in more ideological terms as a straightforward privatisation of parts of the criminal justice system (see for instance much of National Association of Probation Officer's output in relation to the proposed reforms).

To some extent this debate is reflective of the emerging theoretical debate around social innovation. On the one hand social innovation might be conceptualised as an extension of the neo-liberal model. Some supporters of social innovation argue that markets provide the most efficient mechanisms to allocate scarce resources and to

\footnotetext{
${ }^{5}$ Although Mulgan et al. (2011) envisage a future in which a market for Social Impact Bonds is created in which large commercial investors would trade in a new class of assets.

${ }^{6}$ http://www.stgilestrust.org.uk/ [Accessed 11 ${ }^{\text {th }}$ June 2013]
} 
achieve highest levels of social impact. The World Economic Forum (2013) for instance defines social innovation entirely within a market approach:

"Social innovation refers to the application of innovative, practical, sustainable, market-based approaches that achieve transformative social and/or environmental change, with an emphasis on under-served populations."

Others would disagree. As XXXXXXXXX note, what is now called neo-liberalism comprises only a selective reading of economic theory (Jones 2012) but that version has come under sustained criticism including philosophical challenges that have perhaps been most eloquently described by Hollis (1987), economic challenges from economists who are concerned the narrow view of humanity neo-liberalism offers does not reflect the full human experience (Stiglitz 2009 and Sen, 1977) and empirical challenges from behavioural economists who demonstrate that people are not as rational as we like to believe (see Thaler and Mullainathan, 2008 and references therein). Indeed, social innovation is 'distinct from economic innovation because it is about satisfying needs not provided for by the market' and it is often a consequence of market failure (OECD, 2011). 
However, if we reject neoliberalism as the theoretical basis of social innovation it is not clear what should take its place. To date, neither position has been clearly theorized leaving social innovation open to the risk that it is 'all things to all people'.

\section{How can policy makers promote social innovation in the criminal justice system?}

If social innovation is key to criminal justice reform, how can a social innovation environment be enabled, fostered and nourished in the criminal justice system? What policy mechanisms are there to support social innovation and what resources are needed to start and sustain socially innovative practices? One of the difficulties in providing clear recommendations lies in the broad application of social innovation that cuts across different policy sectors. Individual policy areas have institutional and regulatory frameworks, target groups and anticipated policy outcomes specific to them. What is effective in one sector may not work in the criminal justice system. However, whilst for instance, social innovation fostering entrepreneurship, addressing the needs of people in care or environmental issues have different preambles, they share some basic social innovation principles. We may be able to offer broad recommendations for how create a social innovation friendly environment within criminal justice policy. 


\section{Mission and objectives}

Successful social innovation strategies have mission statements that clearly address the anticipated outcomes of the innovative intervention. These strategies build on mixed economy approaches and draw on cross-sectoral partnerships between the public and private sector, the grant economy, individual innovators and social entrepreneurs (Nicholls and Murdock, 2012; Leadbeater, 2007). If not already present partnerships need to be created and inhibitors preventing cooperation have to be removed. Social innovations tend to be bottom up. Communities are best placed to understand social problems and their underlying local complexities. This local expertise should be harnessed, mobilised and communities' capacity to act should be increased during the development and implementation of policy (Social Innovation Europe, 2012). Social innovation is essentially a co-creative practice and active stakeholders involvement driving and taking ownership of the innovation process is an important ingredient of success and a multiplier assuring high impact and sustainability of innovation projects.

In the criminal justice system reducing offending and re-offending will be key to the mission, however, just as social innovation typically combines goal oriented and 
process oriented innovation such that social innovations are those 'innovations that are social in both their means and their ends' so in the criminal justice system the means adopted to achieve justice are integral to the achievement of justice. Consider for instance the question of 'why people obey the law' (Tyler, 2006). Studies show that they do so because they believe it is legitimate, not because they fear punishment (ibid.). As Tyler (2009) points out, the dominant approach to regulation in use today is deterrence, but this is costly and minimally effective. We see this clearly in the criminal justice system where, for example, numerous studies show that prison is relatively ineffective either as a deterrent or incapacitator (see for instance Liedka et al., 2006). As Tyler notes

"it is increasingly recognized that we want more from people than rulefollowing, however it is motivated. Legal authorities are increasingly focused upon the benefits of active public cooperation .... The legal system, in particular the police, needs voluntary help from the public." (Tyler, 2009: 312) This is most obvious in policing where modern approaches to community policing are particularly reliant on individuals and communities engaging with the police in reporting crime, joining residents meetings, forming neighbourhood watch groups, etc.. Clearly these types of voluntary activity are not effectively motivated by the risk 
of punishment (Tyler, 2009). There is evidence that such voluntary activity is more effective where social capital is higher (Sampson et al., 1997). We would argue that social innovation is an important mechanism for capturing the benefits of soft local infrastructures such as social capital and for promoting co-production and civic engagement. Thus social innovation is not just a useful source of new ideas in criminal justice, in the shaping of those ideas legitimacy in criminal justice is replenished and renewed.

So, in addition to reducing offending and re-offending, part of the mission for social innovation in the criminal justice system should therefore be the maintenance and renewal of legitimacy and while the precise role of citizens volunteering in the system might change over time, their continued involvement is crucial. This is perhaps the most important multiplier effect of social innovation that in encouraging active citizenship and though mobilising communities local social capital becomes selfperpetuating, it increases communities' capacity to act and makes local communities resilient. However, there is a risk here that goes to the heart of current reforms to the English and Welsh criminal justice system. Is any commitment to social innovation that is made intended to refresh the legitimacy of the criminal justice system by encouraging greater accountability and local participation (Ministry of Justice, 2010) or 
is it just a 'smokescreen' for an ideologically-driven privatisation programme. The risk is exacerbated given the contested nature of social innovation. This risk is clear when we consider how best to create a market for social innovation, or indeed whether a market is needed at all.

\section{Creating a local social innovation market place}

The private sector has traditionally been driven by financial returns, innovative products with high return on investment upside tend to attracted additional capital. As we noted above a similar market based model can be tested for social innovation investments and social impact returns. If we treat social innovation as an extension of market ideology into the social then, from the perspective of an economist in the neoliberal tradition the key challenge will be to provide free market conditions in which social innovation can flourish. Important macro level policy instruments to achieve this might include the marketization of public services, de-regulation, fiscal measures such as tax incentives, lowering of compliance costs and competitive results driven procurement to create a level playing field (Goldsmith et al., 2010).

If we doubt that social innovation is best theorised as an extension of neoliberalism and suggest different theoretical underpinnings then different policy instruments will 
be required. Social services and markets are often seen as opposites on a value scale. Markets are generally perceived as profit driven while social services have altruistic and moral motives. Social innovation suggests a re-evaluation of the way in which 'return' is measured. Social investors are market participants who also look to maximize their return on investment. Return here is not necessarily monetizeable (although cost savings do play a role in the increasing attention social innovation received from policy makers) but it may be primarily measured in social values such as for instance the level of well being, improvement in the quality of life, the level of integration of hard to reach and vulnerable population groups, the frequency and intensity of shared and participatory local action as well as increased levels of social cohesion and a general sense of community (see for instance Pol and Ville (2009) who see in the improvement of the quality and quantity of life the ultimate end of social innovation). The Ministry of Justice has signalled its desire to see providers of rehabilitation services "tackling offenders' broader life management issues" (Ministry of Justice, 2013b: 17). It also recognises the need for offenders to be able to access a range of public services provided by other Government departments and agencies in order to tackle the multiple issues that offenders often have. Again, this might provide opportunities for social innovators to re-model criminal justice services as part of a broader social justice offer - a model that might fit well with personalisation, given 
that personalisation is likely to encourage an understanding of offender need that is more holistic rather than limited to managing criminogenic needs.

The latest criminal justice reforms favour a mixed economy of criminal justice provision, which might provide a range of opportunities from social innovation either from within existing organisations involved in the criminal justice system or from new organisations. If this is to happen then the ability of Ministry of Justice, as commissioners, to widen the supplier base and create a genuinely mixed economy in which the advantages of public, private and not-for-profit organisations can all play a part will be key. In earlier statements this seemed to be a central part of the new commissioning strategy. A key element seemed to be a move away from central control and towards greater decentralisation. In 2010 the Ministry of Justice was arguing for:

“. . . a move away from centrally controlled services dominated by the public sector, towards a more competitive system that draws on the knowledge, expertise and innovation of a much broader set of organisations from all sectors." (Ministry of Justice, 2010: 8)

On paper this approach fits well with the promotion of social innovation. However, in 
reality, the 'rehabilitation revolution' has generally favoured new market entrants that, whether drawn from the private or not for profit sectors, are large, commercially driven organisations. In part, this is the result of the payment by results model that has been implemented. Only large organisations with substantial capital reserves, or access to substantial flows of credit can take on the risk of payments for reductions in 12 month re-offending rates that will take longer still to be proven (XXXXXXXX). The intention to use a national commissioning model for rehabilitation services divided into 21 geographic contract areas (Ministry of Justice, 2013b) might further hamper social innovation. At the very least it places the responsibility for social innovation very much in the hand of the big, private sector 'primes' who are likely to win the bulk of contracts.

Localism

Social impact markets are inherently local and provide infrastructure, information, and incentives "to enable individuals or institutions to allocate financial, volunteer, or inkind resources with the expectation of those resources resulting in social impact" (Wolk, 2012: unnumbered). It has often been a characteristic of social innovation that change agents are located in local communities, or if in large organisations, at the 
service delivery level. Social innovation equally involves building communities, involving different stakeholders and creating sustainable collaborative partnerships between citizens, local communities civil society organisations (Kunnen et al.' 2013; Crutchfield and McLeod-GrantStanford, 2012) with innovations being diffused through communities of interest. In this 'thick social' model of social innovation, the policy challenge is to create a social innovation culture among people that allows them to lever and upscale socially innovative practices. This requires awareness and support for grass root developments. In policy terms, solutions will not be found in macroeconomic policy adjustments alone, but will need to take account of the interplay between government policy, social and cultural norms and individual and social capacity (Moulaert et al., 2007; Moulaert et al., 2010). In particular, local resources the way in which localities are embedded in external networks, soft infrastructures and intangible assets such as intellectual property and social capital - will be important pillars of sustainable economic activity of the kind suggested by social innovation. In promoting localism, policy instruments might intervene on meso and micro-levels and include open governance, public private partnerships, flexible bureaucracies, innovative procurement and local urban regimes. For a practical example take personalisation in the social care sector. In social care policy measures have included reviewing regulator and legislative barriers that hamper micro-enterprises and 
discouraging exclusive use of commissioning approaches such as 'Preferred Provider' lists which are inimical to innovative organisations, micro-enterprises and start-ups.

Mixed economies and the use of local community based resources to sustain or reinstate services that meet social needs is a central pledge of the Conservative Party.' 'Building the Big Society', a flagship policy of the 2010 Conservative Party Manifesto (Conservative Party, 2010), aims to streamline government involvement through a public service reform that opens up service provision to civil society organisations and the private sector. The Big Society policy also looks to redistributes responsibility for public services away from the state and to local communities and individual members of society and therefore encourages active citizenship. While essentially a policy to reduce public spending, the government also provides financial stimulus and seed corn money via specifically designed channels such as the Big Society Bank (now Big Society Capital set up in $2012^{7}$ ).

There is a strong narrative in support of localism in criminal justice reform (see for instance, Clear and Karp, 2000; Commission on English Prisons, 2009). Localism is increasingly seen as an approach which will lead to more correctly aligned incentives as well as making it more likely interventions will be supported and be successful.

\footnotetext{
${ }^{7}$ http://www.bigsocietycapital.co.uk
} 
Commissioning rehabilitation across larger, regional areas will necessitate lead contractors in each area being large entities that are "capable of bearing the financial and operational risks" (Ministry of Justice, 2013b: 16). The Ministry argues that “. . responsiveness to local needs does not necessitate local commissioning, as diversity can be recognised as part of commissioning at a larger scale ..." (Ministry of Justice, 2013b: 25). However, a national commissioning model will raise issues about the potential for localised approaches to develop. When investigating Justice Reinvestment the Justice Committee (2009) noted the squeeze that government policy puts on smaller local organisations in favour of larger commercial enterprises and commentators have already noted the risk that payment by results models in the criminal justice system pose to small, particularly voluntary sector organisations (see for example, XXXXXXXXX). The Ministry of Justice (2013b) argues that it will take steps to ensure that smaller voluntary sector organisations are part of the commissioning arrangements it enters into and that their role is sustainable.

\section{Information and democratisation}

It has been estimated that the social investment market could be as big as $\$ 500$ billion within the next decade. It is thus not surprising that the sector has become 
increasingly interesting for investors. Nevertheless, the social investment market remains relatively small, inefficient and embryonically (Cabinet Office, 2011). This is partly due to lack of knowledge of the peculiarities of the social economy. For a local social impact market to function effectively, information flow has to be guaranteed between demand (communities, organisations and individuals) and supply of services and products (know how, labour, etc.). In other words, demand and supply needs to be understood by those interested in serving a market by developing new products and services to sell in it. Intermediaries with in-depth knowledge of specific policy areas play therefore an important role in linking local providers with large-scale funders like the Social Innovation Fund ${ }^{8}$ in the US or Big Society Capital.

As we have already noted, Justice Reinvestment is a form of social innovation distinguishable from other approaches to criminal justice programmes in the extent to which it is a data-driven approach, requiring a capacity and capability to collate data, analyse it and make decisions based on interpretation of the results (XXXXXXXX). In the criminal justice system local information flow between providers is not straightforward. For instance, consider the difficulties of undertaking justice mapping in the UK as described by XXXXXXXXX or the challenges local community safety

\footnotetext{
${ }^{8}$ http://www.whitehouse.gov/administration/eop/sicp/initiatives/social-innovation-fund
} 
partnerships have faced when undertaking sharing data (Chainey, 2010). Engaging local communities in this process adds additional complexity and is likely to be most problematic in the high crime, high offender communities where social innovation is most needed. These communities often lack social capital and capacity to identify and use resources essential for the development of innovative solutions. Experience in other sectors suggests that lack of expertise and skills gap is an important inhibitor for innovation (Taylor, 2004).

In the UK there are promising signs here. In recent years the UK government has implemented a Transparency Agenda ${ }^{9}$ (Cabinet Office, 2012) and as a part of this, has made available a growing number of public sector data sets. Together with ever evolving data processing and mapping tools this is opening up possibilities for analysis which may underpin new socially innovative projects in the UK. But how will capacity be built within the criminal justice sector and among local communities to utilise this data?

Risk

\footnotetext{
${ }^{9}$ See http://data.gov.uk
} 
Innovation is an uncertain process (Souder and Monaert, 1992; Jalonen, 2011) that is based on trial and error and associated with the risk of failure (Parsons, 2006; Potts, 2009; Bhatta, 2003). As innovation is fraught with uncertainty, Dodgson et al. (2005), for example, have pointed out that there is a broad understanding in the innovation research that the innovation process requires experimentation and a tolerance within institutions for both risk-taking and failure. Before up-scaling new ideas, these need to be prototyped, piloted and implemented on a small scale allowing for impact evaluation and, if necessary, further refinement in order to achieve maximum impact and to avert catastrophic failure (Murray, 2010). A social innovation friendly environment encourages people and organisations to try-out new ideas to existing issues and problems.

Risk taking in criminal justice is never straightforward. As Berman and Fox (2010) note, the criminal justice sector has been particularly slow to embrace the value of trial and error, although as they also demonstrate we often learn as much from failed criminal justice initiatives as from successful ones. Looking at current criminal justice policy in England and Wales it is not clear that using $\mathrm{PbR}$ as a financial instrument will promote risk taking. Mathew Taylor (2013) in a thought provoking blog contribution highlighted the difficult balance between risk taking and innovation in the CJS. Taylor points out that in rehabilitation PbRs will drive private providers to offer services to those people 
that are most likely to meet the outcome with the least effort. More difficult cases that carry a high risk of failure will be left to deal with in the public sector. To regulate risk, private providers participating in criminal justice $\mathrm{PbR}$ schemes are likely to apply a 'skim' and 'park' strategy (see also XXXXXXXX). Taylor makes two important points: First, innovation is sector dependent. PbR may work in some sectors but they are likely to be less effective in offender rehabilitation with its particular client group. Second, $\mathrm{PbR}$ is a high risk strategy for service providers. Providers will be under immense pressure to avert failure and actual innovation will therefore be only minimal. Moreover, because of limited profit margins and an overly emphasis on outcome (reoffending) rather than process (rehabilitation) there is little incentive for providers to share information with other organisations in the sector.

\section{Conclusion}

Despite substantial effort to improve rehabilitation, re-offending rates remain high in the United Kingdom. To make criminal justice more effective the government suggested innovative strategies that include a combination of market testing, a diversification of the supplier base (mixed economy) and a focus on outcome oriented 
commissioning strategies (payment by results). This 'rehabilitation revolution' is consistent with a wider public reform agenda.

In recent years, social innovation has been brought forward as a response to societal challenges. In this paper we argued that historically social innovation had a prominent role in criminal justice and over recent decades some innovative practices such as justice re-investment and restorative justice moved from the margins to the centre. However, if social innovation is to flourish in the criminal justice sector there will clearly be an important role for lead contractors in the forthcoming competition for rehabilitation services to demonstrate a real commitment to creating an environment in which social innovation is promoted. This will be challenging when they are also being asked to reduce costs while managing offenders' risk. On the other side of the commissioning table the Ministry of Justice will need to think carefully about the facilitators of social innovation and ensure that these are part of its assessment strategy when letting rehabilitation services.

A criminal justice strategy for social innovation would combine a mixture of top-down strategies that facilitate greater social innovation with scope for bottom-up development. Based on our analysis of current criminal justice policy we argue that while some of the top-down, macro conditions are being put in place that could 
facilitate social innovation, the government has, to date, assumed that the market will create the community-level or bottom-up conditions. However, the social innovation literature is ambiguous about this. Indeed social innovation is often a consequence of market failure (OECD, 2011) and government may thus have a more active role to play in promoting social innovation. We agree with Goldsmith et al. (2010) that to achieve greater diversity and a mixed provider base the government can use macro level policies to lower compliance costs in order to create a level playing field for different market participants.

More specifically this could also include consideration of, among other areas:

- $\quad$ Commissioning. In the United Kingdom, 50 percent of all social enterprises trade with the public sector and social enterprises operating in the most deprived communities are more likely to have the public sector as their main customer (Social Enterprise UK, 2011). Public sector funding streams in the criminal justice system should be diversified and localised to make social innovation resilient and sustainable in cyclical environments. One funding mechanism that might provide a means of delivering the breadth of services required is Community Budgets (Cabinet Office, 2011). 
- $\quad$ Financing. We argued that because of associated risk and the requirement of pre-financing $\mathrm{PbR}$ could be an additional barrier to the market for small organisations. Socially innovative individuals lack collaterals and 'social return on investment' does not follow traditional financial ratio modelling. Social innovators therefore find it difficult to draw on the credit facilities of the traditional banking system. In recent years, microcredit (i.e. access to very small scale loans) has become an important source of finance for small innovative initiatives and entrepreneurship specifically in international development. If the government is committed to diversifying its supplier base it needs to make market barriers permeable and allow smaller and innovative providers access to seed corn grants (Antohi, 2009).

- Regulatory frameworks. Innovation is an uncertain process that carries the risk of failure and requires experimentation. Innovators, public and private investors need to manage innovation risks. Risk management can be facilitated though innovation friendly legal frameworks, shared ownership and alternative ways to finance start-ups. Regulatory frameworks, inspection regimes, the availability of different organizational forms and attitudes to risk and reward will all shape the opportunities for social innovation to take place. 
Embracing and promoting social innovation within the criminal justice system would help lay the foundations for transformative change and strengthen the legitimacy of the system. One defining feature of social innovation is to provide insights and develop capacity that endures and can be utilised by others. Mulgan et al. (2007: 35) note that "social innovations, unlike most technological ones, leave behind compelling new social relationships between previously separate individuals and organisations". In this sense Social Innovation provides a 'double benefit', it can help in finding solutions to pressing social needs, and the process of social innovation is itself beneficial. In other words, it implies beneficial, transformative change, rather than mere incremental improvements in services, transformative changes that strengthen the legitimacy of the whole system. 


\section{Bibliography [NOTE SOME REFERENCES REMOVED TO PRESERVE ANONYMITY]}

6 P and Peck E (2004) 'Modernisation': the ten commitments of New Labour's approach to public management? International Public Management Journal Vol.7(1): 1-18.

Allen R (2007) From restorative prisons to justice reinvestment in Allen, R. and Stern, V. (eds.) Justice Reinvestment - a new approach to crime and justice, London: International Centre for Prison Studies Antohi, M (2009) Microfinance, Capital for Innovation. In: MacCallum, D Moulaert, F Hillier, J Haddock SV (eds) Social Innovation and Territorial Development. Farhnham: Ashgate.

Barroso JM (2009) ‘How to boost "social innovation". http://europa.eu/rapid/pressrelease IP-09-81 en.htm (accessed 5 July 2013).

Berman G and Fox A (2010) Trial and Error in Criminal Justice Reform: Learning from Failure. Washington D. C.: The Urban Institute Press.

Bhatta G (2003) Don't just do something, stand there! - revisiting the issue of risks in innovation in the public sector. The Innovation Journal: A Special Issue on Innovation in Governance, Vol.8 (2). 
Braithwaite J (2002) Restorative Justice and Responsive Regulation. Oxford: Oxford University Press.

Cabinet Office (2012) Open data white paper: unleashing the potential. London:

Cabinet Office.

Cabinet Office (2013) Prime Minister hails social investment as 'a great force for social change on the planet'. News Release June 6th. London: Cabinet Office.

Cadora E (2007) Justice reinvestment in the US. In Allen R and Stern V (eds) Justice Reinvestment - A New Approach to Crime and Justice. London: International Centre for Prison Studies, King's College.

Cameron D (2010) PM speech on wellbeing. London: The Prime Minister's Office, 10 Downing Street. Novermber $25^{\text {th. }}$.

Chainey S (2010) Information sharing for community safety: Guidance and practice advice. London: Home Office.

Chambers M (2013) Expanding payment by results: strategic choices and recommendations. London: Policy Exchange.

Clear TR and Karp DR (2000) Community justice: a conceptual framework. Boundary Changes in Criminal Justice Organizations Vol.2. 
Commission on English Prisons (2009) Do better do less: the report of the Commission on English Prisons Today. http://www.prisoncommission.org.uk.

Conservative Party (2010) Invitation to join the government of Britain. The Conservative Manifesto 2010. www.conservatices.com.

Crutchfield LR and McLeod-GrantStanford H (2012) Local Forces for Good. Social Innovation Review, Summer.

Disley ER, Scraggs J, Burrowes E and Culley, D (2011) Lessons learned from the planning and early implementation of the social impact bond at HMP Peterborough. London: Ministry of Justice.

Dodgson M, Gann D and Salter A (2005) Think, Play, Do. Oxford: Oxford University Press.

Dolan P, Layard R and Metcalfe R (2011) Measuring Subjective Wellbeing for Public Policy: Recommendations on Measures. London: LSE.

European Commission (2010) Empowering people driving change social innovation in the European Union. Brussels: Bureau of European Policy Advisors.

Franz, H.W., Hochgerner, J., and Howaldt, J., 2012. Challenge social innovation: and introduction. In: Franz, H.W., Hochgerner, J., and Howaldt, J., (eds.) Challenge social 
innovation, potentials for business, social entrepreneurship, welfare and civil society. Heidelberg: Springer.

Goldsmith, S; Georges, G and Burke, TG (2010) The Power of Social Innovation: How

Civic Entrepreneurs Ignite Community Networks for Good. San Francisco: Whiley.

Goldstein H (1990) Problem-Oriented Policing. New York: McGraw Hill Inc.

Harper G and Price G (2011) Defra evidence and analysis series paper 3A framework for understanding the social impacts of policy and their effects on wellbeing. A paper for the Social Impacts Taskforce April. London: Department for Environment Food and Rural Affairs.

Her Majesty's Government (2010) The Coalition: our programme for government. London: Cabinet Office.

Her Majesty's Government (2011) Open public services white paper. London: Cabinet Office.

Her Majesty's Treasury (2009) Operational efficiency programme: back office operations and IT. London: HM Treasury.

Hochgerner, J; Franz, HW; Howaldt, J and Schindler-Daniels, A 2011 Vienna Declaration Challenging Social Innovation. http://www.socialinnovation2011.eu/wp- 
content/uploads/2011/09/Vienna-Declaration final 10Nov2011.pdf (Accessed June 2013).

Hollis M (1987) The Cunning of Reason. Cambridge: Cambridge University Press.

Hornby S (2013) 'Community Payback and Rehabilitation', Ethos.

Howaldt J and Schwarz, M (2010) Soziale Innovation - Konzepte, Forschungsfelder und -perspektiven. In: Howaldt, J and Jacobsen, H (Eds) Soziale Innovation; Auf dem Weg su einem postindustriellen Innovationsparadigma. Mörelnbach: VS Verlag.

Jacobsen, $\mathrm{H}$ and Jostmeier, M (2010) Dienstleistungsinnovation als soziale Innovation: neue Optionen für produktive Aktivität der NutzerInnen. In: Howaldt, J and Jacobsen, $\mathrm{H}$ (Eds) Soziale Innovation; Auf dem Weg su einem postindustriellen Innovationsparadigma. Mörelnbach: VS Verlag. Jalonen H (2011) The uncertainty of innovation: a systematic review of the literature. Journal of Management Research Vol.4 (1): 1 - 47.

Jones DS (2012) Masters of the Universe: Hayek, Friedman, and the Birth of Neoliberal Politics. Princington: Princeton University Press.

Joyce P (2011) Policing Development and Contemporary Practice. London: SAGE Publications Ltd. 
Justice Committee (2008) Towards effective sentencing. Fifth Report, Session 2007-8. London: The Stationary Office.

Justice Committee (2009) Cutting crime: the case for justice reinvestment. London: The Stationary Office Limited. Available at

http://www.publications.parliament.uk/pa/cm200910/cmselect/cmjust/94/94i.pdf (accessed 2 November 2012).

Kania, J and Kramer, M (2011) Collective Impact. Stanford Social Innovation Review. Winter.

Kunnen, N MacCallum, D Young, S (2013) Resaerch Strategies for assets and strengths based community development. In Moulaert, F MacCallum, D Mehmood, A Hamdouch, A (2013) The International Handbook on Social Innovation: Collective Action, Social Learning and Transdisciplinary Research. Northhampton: Edward Elgar Publishing Limited

Leadbeater, C (2004) Personalisation through Participation; A New Script for Public Services. Londond: Demos.

Leadbeater, C (2007) A social enterprise think piece for the Office of Third Sector, November.

Liedka RV, Piehl AM and Useem B (2006) The crime-control effect of incarceration: does scale matter? Criminology \& Public Policy Vol.5(2): 245-276.

MacCallum, D Moulaert, F Hillier, J Haddock SV (2009) Social Innovation and Territorial Development. Farhnham: Ashgate. 
Mair G and Millings M (2011) Doing justice locally: The north Liverpool community justice centre. London: Centre for Crime and Justice Studies.

Michaelson J, Mahony S and Schifferes J (2012) Measuring Wellbeing: a Guide for Practitioners. London: NEF.

Mills H, Silvestri A, Grimshaw R, and Silberhorn-Armantrading F (2010) Prison and probation expenditure 1999 - 2009. London: Centre for Crime and Justice Studies. Ministry of Justice (2010) Breaking the cycle: effective punishment, rehabilitation and sentencing of offenders. London: Home Office.

Ministry of Justice (2012) Press release $8^{\text {th }}$ November 2012: Next steps for prison competition, https://www.gov.uk/government/news/next-steps-for-prisoncompetition--2 (accessed 3 July 2013).

Ministry of Justice (2013a) Proven re-offending statistics quarterly bulletin April 2010 to March 2011, England and Wales. London: Ministry of Justice.

Ministry of Justice (2013b) Transforming rehabilitation - a revolution in the way we manage offenders. London: Ministry of Justice.

Ministry of Justice (2013c) Transforming rehabilitation - a strategy for reform. London: Ministry of Justice. 
Moulaert, F Martinelli, F González, S and Swyngedouw E (2007) Introduction: Social Innovation and Governance in European Cities Urban Development Between Path Dependency and Radical Innovation. European Urban and Regional Studies. July; 14 (3).

Moulaert, F Martinelli, F Swyngedouw E and González, S and (2010) Can Neighborhoods Save the City; Community Develppment and Social Innovation. London: Routledge.

Moulaert, F MacCallum, D Mehmood, A Hamdouch, A (2013) The International Handbook on Social Innovation: Collective Action, Social Learning and Transdisciplinary Research. Northhampton: Edward Elgar Publishing Limited.

Mulgan G (2006) The process of social innovation. Innovations: Technology, Governance, Globalization, 1 (2): 145-162.

Mulgan G, Tucker S, Rushanara A, and Sanders B (2007) Social innovation: what it is, why it matters and how it can be accelerated. Skoll Centre for Social Entrepreneurship. Mulgan M, Reeder R, Aylott M and Bo'sher L (2011) Social impact investment: the challenge and opportunity of social impact bonds. London: The Young Foundation. Mumford, M.D., 2002. Social innovation: ten cases from Benjamin Franklin. Creativity Research Journal 14 (2): 253-266.

Murray R, Caulier-Grice J and Mulgan G (2010) The open book of social innovation. The Young Foundation and NESTA. 
Nicholls, A and Murdock, A (2012) The Nature of Social Innovation. In: Nicholls and Murdock (eds) Social Innovatin; Blurring Boundaries to Reconfigure Markets.

Basingstoke, New York: Palgrace Macmillan.

OECD (2011) Fostering Innovation to Address Social Challenges. http://www.oecd.org/sti/inno/47861327.pdf (Accessed September 2013)

Parsons W (2006) Innovation in the public sector: spare tyres and fourth plinths. The Innovation Journal: the Public Sector Innovation Journal 11(2). Article 1.

Phills JA, DeigImeier K and Miller DT (2008) Rediscovering social innovation. Stanford Social Innovation Review 6 (4): 34-43.

Pol, E and Ville, S (2009) Social innovation: Buzz word or enduring term? The Journal of Socio-Economics, Volume 38, Issue 6, December 2009, Pages 878-885

Potts J (2009) The innovation deficit in public services: the curious problem of too much efficiency and not enough waste and failure. Innovation: Management, Policy \& Practice 11(1): 34-43.

Sampson RJ, Raudenbush SW and Earls F (1997) Neighborhoods and violent crime: a multilevel study of collective efficacy. Science 15 Vol. 277 no. 5328: 918-924.

Sen AK (1977) "Rational fools: a critique of the behavioral foundations of economic theory." Philosophy and Public Affairs Vol. 6, no. 4: 317-344. 
Sherman L and Strang H (2007) Restorative Justice: the Evidence. London: Smith Institute.

Social Enterprise UK (2011) Fightback Britain. a report on the state of social enterprise survey 2011. http://www.socialenterprise.org.uk (accessed 5 July 2013).

Social Finance (2010) Press release, social finance releases first social impact bond. Lodond: Social Finance www.socialfinance.org.uk/sites/default/files/SIB March18 PR.pdf (accessed $11^{\text {th } M a r c h ~ 2011) . ~}$

Social Innovation Europe (2012) Financing social impact, funding social innovation in Europe mapping the way forward.

http://ec.europa.eu/enterprise/policies/innovation/files/funding-socialinnovation en.pdf (accessed 5 July 2013).

Souder WE and Moenaert KD (1992) Integrating marketing and R\&D project personnel within innovation projects: an information uncertainty model. Journal of Management Studies 29(4): 485-512.

Stiglitz JE (2009) Globalization and its Discontents. New York and London: W.W. Norton. 
Taylor, M. (2013) Probation PBR - (a lot) more questions than answers. Blog entry May

9. http://www.matthewtaylorsblog.com/public-policy/probation-pbr-a-lot-morequestions-than-answers/ (accessed $1^{\text {st }}$ June 2013).

Taylor R (2004) Skills and innovation in modern workplaces. ESRC Future of Work Programme.

Thaler RH and Mullainathan S (2008) 'Behavioral Economics', The Concise Encyclopedia of Economics. 2nd Edition. Liberty Fund.

Tyler TR (2006) Why People Obey the Law. Precington: Precington University Press.

Tyler TR (2009) 'Legitimacy and criminal justice: the benefits of self-regulation'. Ohio State Journal of Criminal Law Vol.7: 307-359.

Weaver B (2011) Co-producing community justice: the transformative potential of personalisation for penal sanctions. British Journal of Social Work. 41(6):1038-1057. Wolk A (2012) Social impact markets, why a market for social innovations is needed now more than ever. Stanford Social Innovation Review Winter. http://www.ssireview.org/articles/entry/social impact markets (accessed 5 June 2013). 
World Economic Forum (2013) Global agenda council on social innovation 2012-2013. http://www.weforum.org (accessed 5 July 2013).

Young Foundation, 2007. Social innovation: what it is, why it matters, how it can be accelerated. http://www.youngfoundation.org/node/460 (accessed 5 July 2013). 